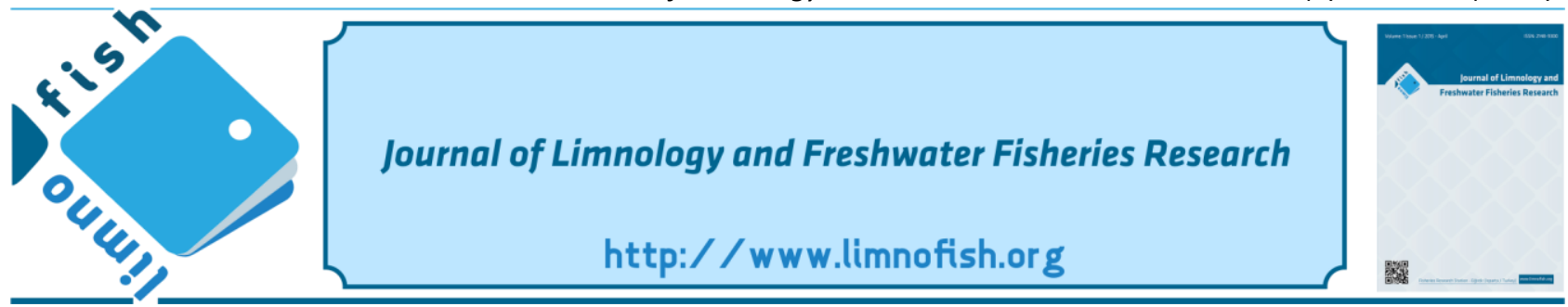

\title{
Assessment of Water Quality in Brackish Lake Bafa (Muğla, Turkey) by Using Multivariate Statistical Techniques
}

\author{
Atakan SUKATAR ${ }^{1}$ (D), Alperen ERTAS ${ }^{1 *}$ (D) , İnci TUNEY KIZILKAYA ${ }^{1}$ (D) \\ ${ }^{1}$ Ege University, Faculty of Science, Department of Biology, 35100 Bornova, İzmir, TURKEY
}

\section{A B STR ACT}

Lake Bafa is one of the biggest lake in the western part of Turkey. It has a great importance in terms of both historical and biodiversity. Lake Bafa which was fed by Büyük Menderes River has become an area where the pollutant factors carried by the river accumulated over time. In this context, the complex physicochemical characteristics of Lake Bafa were evaluated and water quality classes were determined in order to constitute a monitoring pattern. In this research, the water samples were taken monthly from eight different stations located in the Lake Bafa during the two years study period (2015-2017). Total of 22 water quality parameters including atmospheric pressure, temperature, $\mathrm{pH}$, electrical conductivity, total dissolution solids, salinity, turbidity, dissolved oxygen, oxygen saturation, biological oxygen demand, chemical oxygen demand, ammonium, nitrate, nitrite, calcium, sodium, magnesium, potassium, chloride, sulphate total phosphorus and total nitrogen were investigated in water samples. The data obtained were statistically evaluated by using Principal Component Analysis (PCA), Cluster Analysis (CA) and Pearson Correlation Analysis and compared with the limit values reported by various national and international organizations. According to the results PCA, three factors (PCA 1, PCA 2 and PCA 3) explained $79.05 \%$ of the total variance while CA results exhibited three statistically significant clusters. Overall the results suggested that Lake Bafa has been exposed to high amount of pollution and it is generally classified in "Class III-IV" water quality level based on both Klee's method and Turkish Water Pollution Control Regulation.

\section{ARTICLE INFO}

RESEARCH ARTICLE

Received : 27.08.2020

Revised : 20.01.2021

Accepted : 02.02 .2021

Published : 30.12.2021

DOI:10.17216/LimnoFish.774739

* CORRESPONDING AUTHOR

alperenertas@hotmail.com Phone : ++90 5065863792

Keywords: Lake Bafa, physicochemical parameters, water quality

Tuzlu Su Özelliğine Sahip Bafa Gölü’nün (Muğla, Türkiye) Su Kalitesinin Çok Değişkenli İstatistik Analizler Kullanılarak Değerlendirilmesi

Öz: Bafa Gölü, Türkiye'nin batısındaki en büyük göllerden biridir. Hem tarihsel hem de biyolojik çeşitlilik açısından büyük önem taşımaktadır. Büyük Menderes Nehri tarafından beslenen Bafa Gölü, nehrin taşıdığı kirletici faktörlerin zamanla biriktiği bir alan haline gelmiştir. Bu bağlamda Bafa Gölü'nün karmaşık fizikokimyasal özellikleri değerlendirilmiş ve bir izleme modeli oluşturmak amacıyla su kalitesi sınıfları belirlenmiştir. Bu araştırmada, su örnekleri iki yıllık çalıșma döneminde (2015-2017) Bafa Gölü'nde belirlenen sekiz farklı istasyondan aylık olarak alınmıştır. Su numunelerinde atmosfer basıncı, sıcaklık, pH, elektriksel iletkenlik, toplam çözünüş katı madde, tuzluluk, bulanıklık, çözünmüş oksijen, oksijen doygunluğu, biyolojik oksijen ihtiyacı, kimyasal oksijen ihtiyac1, amonyum, nitrat, nitrit, kalsiyum, sodyum, magnezyum, potasyum, klorür, sülfat, toplam fosfor ve toplam azot olmak üzere toplam 22 su kalite parametresi tespit edilmiştir. Elde edilen veriler, Temel Bileşen Analizi (PCA), Kümeleme Analizi (CA) ve Pearson Korelasyon Analizi kullanılarak istatistiki olarak değerlendirilmiş ve çeşitli ulusal ve uluslararası kuruluşlar tarafından bildirilen limit değerler ile karşılaştırılmıştır. PCA sonuçlarına göre, üç faktör (PCA 1, PCA 2 and PCA 3) toplam varyansın \%79,05'ini açıklarken CA sonuçlarıyla istatistiksel olarak anlamlı üç küme tespit edilmiştir. Elde edilen analiz sonuçlarına göre, Bafa Gölü'nün yüksek miktarda kirliliğe maruz kaldığı ve Klee metodu ve Türkiye Su Kirliliği Kontrolü Yönetmeliği'ne göre genel olarak "Sınıf III-IV" su kalitesinde olduğu belirlenmiştir.

Anahtar kelimeler: Bafa Gölü, fizikokimyasal parametreler, su kalitesi

How to Cite

Sukatar A, Ertaş A, Tuney Kızılkaya İ. 2021. Assessment of Water Quality in Brackish Lake Bafa (Muğla, Turkey) by Using Multivariate Statistical Techniques. LimnoFish. 7(3): 271-284. doi: 10.17216/LimnoFish.774739 


\section{Introduction}

Surface water resources such as lakes, rivers and streams have been deteriorated by various factors continuously. Anthropogenic factors are of direct effects on the water systems (Tanyolaç 2004). Population growth, demotechnical improvement, industrial and agricultural activities are mainly impact surface water quality, and cause deterioration of water resources. The Water Framework Directive (WFD) identifying the biological and physicochemical characteristics of water systems and protecting them became an important issue in the last 20 years.

WFD legislation include surface and groundwater, as well as all inland water systems and coastal waters up to one nautical mile. Mainly target of the WFD is to prevent deterioration in the biological and physicochemical status all surface waters. Good status criterion for surface waters is by achieving good biological and physicochemical state by 2015 (European Commission 2000).

In many countries, one of the main environmental problems of lakes are considered nutrient enrichment which cause the Harmful Algal Blooms (HABs) (Oczkowski and Nixon 2008). This encourage the growth of $\mathrm{HABs}$, and this leads to deterioration of water quality along entire ecosystem as a reason of nutrient enrichment ( $\mathrm{Yu}$ et al. 2010). Many lakes in both urban and rural area have disappeared because of pollutant pressures that causes worldwide environmental problem, that's why, regular biomonitoring and assessment research on water systems helps to improve the management strategies for overcome of water pollution (Shuchun et al. 2010) reliable forecast of the quality of lakes, rivers and streams. According to Kazi et al. (2009), the dimensional variations are large and complex data matrix included of high number of physicochemical parameters, which are generally difficult to constitute reliable outcomes. Lately, the application of diverse multivariate statistical processes, like CA and PCA have beenused to identify possible sources that influence aquatic ecosystems (Reghunath et al. 2002; Simeonova et al. 2003; Akkan et al. 2018; Kükrer and Mutlu, 2019; Uncumusaoğlu and Mutlu, 2019; Ustaoğlu and Tepe, 2019; Taş et al. 2019; Ustaoğlu et al 2020; Tokatl1 2020).

Lake Bafa basin is rich as biological diversity. It provides breeding, nursery and wintering area on the coast and islands for about 300.000 birds (Knipping et al. 2008). The lake basin present to us 237 genera, 325 species, 22 subspecies and 7 varieties belonging to 80 familia and 16 endemic species, respectively. Besides the birds there are about 20 fish species with an importance such as critically endangered Anguilla anguilla (Linne, 1758) and endemic species
Chondrostoma meandrense (Elvira, 1987) in the lake (Kuru et al. 2001).

The lake has been under the threat of various environmental pollutants. Büyük Menderes River, which is one of the devastating external pollutant loads, is originated in Dinar district of Afyon province and flows $584 \mathrm{~km}$ to the Aegean Sea. An arm that leaves the river just before it goes into the sea, feeds Lake Bafa. Like a reservoir, Lake Bafa receives industrial, agricultural and domestic wastes of Afyon, Uşak and, Aydın provinces. In addition to the industrial pollution, there is a fish hatchery facility on the shore of Lake Bafa. Organic and chemical substances used in hatcheries are thought to contribute to pollution and salinity increase in the lake. Similarly, there are plenty of olive oil facilities around the lake. It is estimated that the land water from these factories reaches the lake as a result of various leaks or overflowing of black water wells after rain. In agricultural production around the lake, a large amount of fertilizer, pesticide and chemicals are used. Besides those organic and inorganic pollution sources increased salinity levels threatened the biodiversity. According to Sar1 et al. (1999), the fish fauna of the Lake Bafa changed mainly because of the rising salinity levels. Anguilla mirabilis which is one of the third endemic species in the basin become extinct in Lake Bafa (Balık and Ustaoğlu 1989). Cyprinus carpio, Cyprinus nasus, Barilius pectoralis and Silurus glanis were also extinct in the lake due to increased salinity levels and decreased water quality (Mermer 1989; Balık et al. 1992; Balık 1995). Dügel and Kazanc1 (2004), investigated the variations of macroinvertebrate fauna of Büyük Menderes River according to environmental changes. They identified the distribution of 225 benthic macroinvertebrate species influenced significantly by environmental changes. Factors affecting their populations determined as nitrite, nitrate, chloride, orthophosphate concentrations, conductivity, dissolved oxygen levels, ammonium concentration, $\mathrm{pH}$, water temperature, drainage area, and stream. The effects of various external pollutant accumulation directly affect the water quality and biodiversity in Lake Bafa. For this reason, Lake Bafa should be kept under constant observation and investigation.

Due the foreseen of negative impact of some water quality elements on the biodiversity of ecologically important Lake Bafa, we monitored 22 physicochemical components of the lake for 2 years (2015-2017). For this reason, water samples were picked up from eigth different stations of the lake, especially some of the stations were determined from the points where the Büyük Menderes River drains into the lake. The lake classified according to the 
pollution state by using multivariate statistical methods like CA and PCA. With these methods, according to obtained data set, we also determined the sources of pollution.

\section{Materials and Methods \\ Study Area}

Lake Bafa, also known as Çamiçi, is a shallow lake located in the south east of Büyük Menderes delta, with a slightly salty and 21 meters deepest part. The surface area of Lake Bafa is $65 \mathrm{~km}^{2}$ and its surroundings are $50 \mathrm{~km}$. It is $16 \mathrm{~km}$ long, $6 \mathrm{~km}$ wide and 10 meters high from the sea. It is surrounded by mountains covered with forests and maquis, except for the west of the Menderes Plain. The west coast is shallow and covered with swamps. The lake, which was a part of the Aegean Sea in ancient times, remained inside the coast for miles along with the alluviums carried by Büyük Menderes. The most important source that feeds the lake is the waters of the Büyük Menderes River. The eight representative sampling points were chosen for the study. The $7^{\text {th }}$ and $8^{\text {th }}$ stations were chosen as a sampling station where the Büyük Menderes River drains into the Lake Bafa. The other stations were in the lake. The first sampling station was on the south west part of the lake where the restaurants were located. The $2^{\text {nd }}$ station was in the centric and the sampling $3^{\text {rd }}$ and $4^{\text {th }}$ stations were on the eastern part of the lake. The coast of the one of the biggest vilage around the lake were chosen as $5^{\text {th }}$ sampling station. Another sampling station $\left(6^{\text {th }}\right)$ was chosen by the fishing port and the fish hatcheries (Figure 1). The sampling station and their coordinates are given in Table 1 .

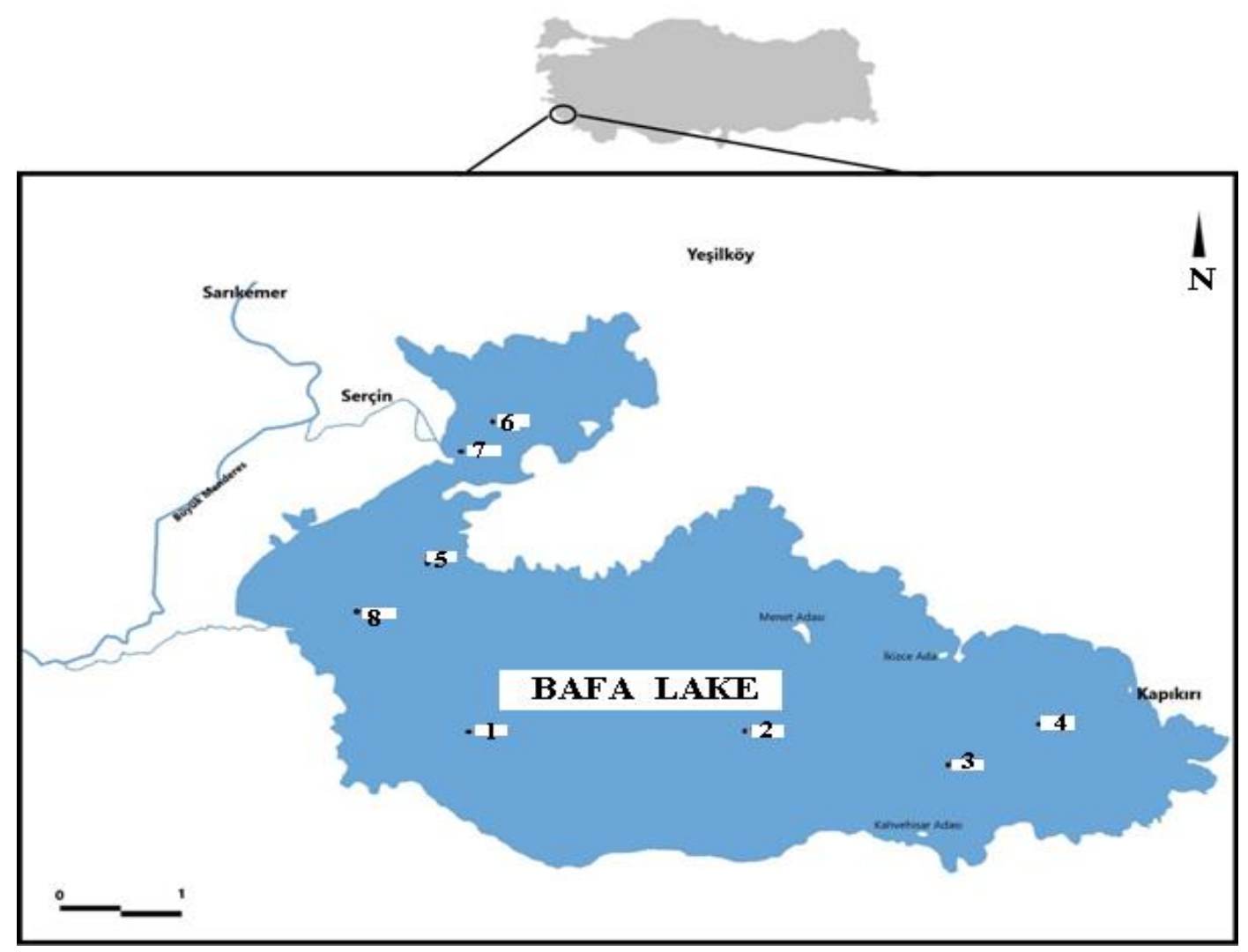

Figure 1. Location of eight stations on Lake Bafa.

Table 1. Latitude and longitude of the stations in Lake Bafa

\begin{tabular}{l|l|l}
\hline Stations & Latitude & Longitude \\
\hline Station 1 & $37^{\circ} 29^{\prime} 35^{\prime \prime} \mathrm{N}$ & $27^{\circ} 24^{\prime} 87^{\prime \prime} \mathrm{E}$ \\
\hline Station 2 & $37^{\circ} 29^{\prime} 76^{\prime \prime} \mathrm{N}$ & $27^{\circ} 27^{\prime} 28^{\prime \prime} \mathrm{E}$ \\
\hline Station 3 & $37^{\circ} 29^{\prime} 29^{\prime \prime} \mathrm{N}$ & $27^{\circ} 29^{\prime} 31^{\prime \prime} \mathrm{E}$ \\
\hline Station 4 & $37^{\circ} 29^{\prime} 29^{\prime \prime} \mathrm{N}$ & $27^{\circ} 31^{\prime} 09^{\prime \prime} \mathrm{E}$ \\
\hline Station 5 & $37^{\circ} 31^{\prime} 49^{\prime \prime} \mathrm{N}$ & $27^{\circ} 24^{\prime} 04^{\prime \prime} \mathrm{E}$ \\
\hline Station 6 & $37^{\circ} 32^{\prime} 67^{\prime \prime} \mathrm{N}$ & $27^{\circ} 233^{\prime} 76^{\prime \prime} \mathrm{E}$ \\
\hline Station 7 & $37^{\circ} 32^{\prime} 19^{\prime \prime} \mathrm{N}$ & $27^{\circ} 244^{\prime} 41^{\prime \prime} \mathrm{E}$ \\
\hline Station 8 & $37^{\circ} 30^{\prime} 46^{\prime} \mathrm{N}$ & $27^{\circ} 22^{\prime} 82^{\prime \prime} \mathrm{E}$ \\
\hline
\end{tabular}

\section{Sample collection and analytical methods}

Taken water samples from eight sampling stations were kept in at $0.5 \mathrm{~m}$ on the basis of monthly, betwen July 2015 and June 2017 in Lake Bafa. By using 2.0 L polyethylene plastic bottles, the water samples were preserve in the study area.

Total of 22 physicochemical variables were monitored over a two year period. In this study, in addition to the physicochemical parameters, their units devices and analytical procedures are demonstrated in Table 2. 
Table 2. Water quality parameters and analytical methods used in Lake Bafa

\begin{tabular}{|c|c|c|c|}
\hline Variables & Abbreviations & Units & Analytical methods \\
\hline Atmosphere pressure & Atm & $\mathrm{mB}$ & Oxi 315i/ SET WTW Oxygenmeter \\
\hline Water temperature & $\mathrm{T}$ & ${ }^{\circ} \mathrm{C}$ & Oxi 315i/ SET WTW Oxygenmeter \\
\hline $\mathrm{pH}$ & $\mathrm{pH}$ & - & $\begin{array}{c}\text { CyberScan Series } 600 \text { Waterproof- } \\
\text { Portable Meter }\end{array}$ \\
\hline Electrical conductivity & $\mathrm{EC}$ & $\mathrm{mS} / \mathrm{m}$ & $\begin{array}{c}\text { CyberScan Series } 600 \text { Waterproof- } \\
\text { Portable Meter }\end{array}$ \\
\hline Total Dissolved Solids & TDS & ppt & $\begin{array}{c}\text { CyberScan Series } 600 \text { Waterproof- } \\
\text { Portable Meter }\end{array}$ \\
\hline Salinity & Salinity & $\mathrm{pt}$ & $\begin{array}{c}\text { CyberScan Series } 600 \text { Waterproof- } \\
\text { Portable Meter }\end{array}$ \\
\hline Turbidity & TU & FAU & $\begin{array}{c}\text { CyberScan Series } 600 \text { Waterproof- } \\
\text { Portable Meter }\end{array}$ \\
\hline Dissolved oxygen & DO & $\mathrm{mg} / \mathrm{L}$ & Oxi 315i/ SET WTW Oxygenmeter \\
\hline Oxygen saturation & Sat. $\mathrm{O}_{2}$ & $\%$ & Oxi 315i/ SET WTW Oxygenmeter \\
\hline Biochemical oxygen demand & BOD & $\mathrm{mg} / \mathrm{L}$ & Spectrophotometric \\
\hline Chemical oxygen demand & COD & $\mathrm{mg} / \mathrm{L}$ & Spectrophotometric \\
\hline Ammonium & $\mathrm{NH}_{4}-\mathrm{N}$ & $\mathrm{mg} / \mathrm{L}$ & Spectrophotometric \\
\hline Nitrite & $\mathrm{NO}_{2}-\mathrm{N}$ & $\mathrm{mg} / \mathrm{L}$ & Spectrophotometric \\
\hline Nitrate & $\mathrm{NO}_{3}-\mathrm{N}$ & $\mathrm{mg} / \mathrm{L}$ & Spectrophotometric \\
\hline Calcium & $\mathrm{Ca}$ & $\mathrm{mg} / \mathrm{L}$ & Flame photometer \\
\hline Magnesium & $\mathrm{Mg}$ & $\mathrm{mg} / \mathrm{L}$ & Flame photometer \\
\hline Potassium & $\mathrm{K}$ & $\mathrm{mg} / \mathrm{L}$ & Flame photometer \\
\hline Sodium & $\mathrm{Na}$ & $\mathrm{mg} / \mathrm{L}$ & Flame photometer \\
\hline Chloride & $\mathrm{Cl}$ & $\mathrm{mg} / \mathrm{L}$ & Spectrophotometric \\
\hline Sulphate & $\mathrm{SO}_{4}$ & $\mathrm{mg} / \mathrm{L}$ & Spectrophotometric \\
\hline Total Phosphate & $\mathrm{TP}$ & $\mathrm{mg} / \mathrm{L}$ & Spectrophotometric \\
\hline Total Nitrogen & $\mathrm{TN}$ & $\mathrm{mg} / \mathrm{L}$ & Spectrophotometric \\
\hline
\end{tabular}

\section{Statistical analysis}

In this study, physicochemical water quality was determined according to Klee (1991) and Turkish Water Pollution Control Regulation (WPCR) (Ministry of Forestry and Water Management).

All mathematical and statistical analyses were made using Excel 2019 (Microsoft Office ${ }^{\mathrm{R}}$ ) and PAST3 software package. On the other hand, Lake Bafa water quality estimation was implemented by using PCA and CA techniques, on the basis of multivariate statistical analysis (Kazi et al. 2009). In addition, Pearson Correlation analysis was carried out to detect significant relationships between the data obtained.

The CA technique based on Bray-Curtis is described as the classification of similar components between the observation or clusters. Hierarchical agglomerative clustering is the routine method which ensures similarity relationship among the all data set, and is demonstrated by a dendrogram tree diagram (Sommerfield 2008; Yoshioka 2008).

\section{Results}

\section{Physicochemical Parameters}

The results of the analyzed physicochemical variables of water in eight sampling stations along the lake are presented in Table 3.

\section{Pearson Correlation Anaysis}

Statistically significant relationships and correlation coefficient values determined between physicochemical dataset determined in brackish Lake Bafa are given in Table $4(n=8)$. 
Table 3. Range, mean and standard deviation of water quality parameters at the stations in Lake Bafa during 2015-2017

\begin{tabular}{|c|c|c|c|c|c|c|c|c|c|}
\hline \multicolumn{2}{|c|}{ Parameters } & \multirow{2}{*}{$\begin{array}{c}\text { Sta. } 1 \\
194-219\end{array}$} & \multirow{2}{*}{$\begin{array}{c}\text { Sta. } 2 \\
196-226\end{array}$} & \multirow{2}{*}{$\begin{array}{c}\text { Sta. } 3 \\
198-259\end{array}$} & \multirow{2}{*}{$\begin{array}{c}\text { Sta. } 4 \\
219-252\end{array}$} & \multirow{2}{*}{$\begin{array}{c}\text { Sta. } 5 \\
166-184\end{array}$} & \multirow{2}{*}{$\begin{array}{c}\text { Sta. } 6 \\
165-228\end{array}$} & \multirow{2}{*}{$\begin{array}{c}\text { Sta. } 7 \\
126-355\end{array}$} & \multirow{3}{*}{$\begin{array}{c}\text { Sta. } 8 \\
141-207\end{array}$} \\
\hline Atm. & $\mathrm{R}$ & & & & & & & & \\
\hline$(\mathrm{mB})$ & $\mathrm{M} \pm \mathrm{Sd}$ & $203 \pm 11.3$ & $211 \pm 12.6$ & $230 \pm 25.1$ & $241 \pm 15.6$ & $172 \pm 8.54$ & $185 \pm 28.7$ & $239 \pm 93.5$ & \\
\hline \multirow{2}{*}{$\begin{array}{l}\text { Temp. } \\
\left({ }^{\circ} \mathrm{C}\right)\end{array}$} & $\mathrm{R}$ & $11.1-29.1$ & $11.2-28.6$ & $11.4-29.9$ & $12.5-29.1$ & $10.4-28.3$ & $9.9-26.6$ & $9.8-27.8$ & $10.5-27.2$ \\
\hline & $\mathrm{M} \pm \mathrm{Sd}$ & $20 \pm 7.4$ & $19.9 \pm 7.2$ & $19.8 \pm 6.79$ & $20.9 \pm 6.84$ & $19.3 \pm 7.32$ & $18.7 \pm 6.85$ & $19.2 \pm 7.38$ & $19.2 \pm 6.94$ \\
\hline \multirow[t]{2}{*}{$\mathrm{pH}$} & $\mathrm{R}$ & 6.9 & $67-$ & & & & & & \\
\hline & $\mathrm{M} \pm \mathrm{Sd}$ & $7.0 \pm 0.15$ & $6.87-0.17$ & $6.9 \pm$ & $6.9 \pm$ & $7.0=$ & $6.9=$ & 7.2 & $7.0 \pm 0.27$ \\
\hline \multirow{2}{*}{$\begin{array}{l}\mathrm{EC} \\
(\mathrm{mS} / \mathrm{m})\end{array}$} & 11 & 175 & & & & & & & \\
\hline & $\pm \mathrm{Sd}$ & $206 \pm$ & $190=$ & .5 & & 57 & 205 & .2 & 197 \\
\hline \multirow{2}{*}{$\begin{array}{l}\text { TDS } \\
\text { (ppt) }\end{array}$} & $\mathrm{R}$ & & & & & & & & \\
\hline & $\mathrm{I} \pm \mathrm{Sd}$ & 195 & 191 & $194=$ & 189 & 189 & $175 \pm 3$ & 9.6 & 197 \\
\hline \multirow{2}{*}{$\begin{array}{l}\text { Salinity } \\
\text { (pt) }\end{array}$} & In & & & & & & & & \\
\hline & $\pm \mathrm{Sd}$ & $12 \pm$ & $12=$ & 11.9 & 12. & 12.2 & 12. & 12.4 & 12. \\
\hline \multirow{2}{*}{$\begin{array}{l}\text { Turbidity } \\
\text { (FAU) }\end{array}$} & $\mathrm{R}$ & 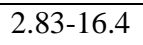 & & & & & $17.3-$ & 5 & \\
\hline & $\mathrm{M} \pm \mathrm{Sd}$ & 11.4 & & $12=$ & 13. & 11 & & & \\
\hline \multirow{2}{*}{$\begin{array}{l}\mathrm{DO} \\
(\mathrm{mg} / \mathrm{l})\end{array}$} & 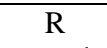 & & & & & & & & \\
\hline & $\pm \mathrm{Sd}$ & & & & & & & .32 & \\
\hline \multirow{2}{*}{$\begin{array}{l}\text { Sat. } \mathrm{O}_{2} \\
(\%)\end{array}$} & $\mathrm{R}$ & & & & & & & & \\
\hline & & 105 & 103 & & & & & & \\
\hline \multirow{2}{*}{$\begin{array}{l}\mathrm{BOD} \\
(\mathrm{mg} / \mathrm{l})\end{array}$} & K & & & & & & & & \\
\hline & $\mathrm{I}+\mathrm{S}$ & 5 . & 6.0 & 6.2 & 6.3 & 8.2 & 9.4 & & 9.0 \\
\hline \multirow{2}{*}{$\begin{array}{l}\mathrm{COD} \\
(\mathrm{mg} / \mathrm{l})\end{array}$} & $\mathrm{R}$ & 0 & & & & & & & \\
\hline & $\pm \mathrm{Sd}$ & 2.3 & & 3.2 & 2.5 & 2.6 & & 03 & \\
\hline \multirow{2}{*}{$\begin{array}{l}\mathrm{NH}_{4}-\mathrm{N} \\
(\mathrm{mg} / \mathrm{L})\end{array}$} & N & & & & & & & & \\
\hline & $\pm \mathrm{S}$ & & & & & & 26 & .47 & .32 \\
\hline \multirow{2}{*}{$\begin{array}{l}\mathrm{NO}_{2}-\mathrm{N} \\
(\mathrm{mg} / \mathrm{L})\end{array}$} & $\mathrm{R}$ & & & & & & & & \\
\hline & $\mathrm{M} \pm \mathrm{Sd}$ & & & & & & & 02 & \\
\hline \multirow{2}{*}{$\begin{array}{l}\mathrm{NO}_{3}-\mathrm{N} \\
(\mathrm{mg} / \mathrm{L})\end{array}$} & $\mathrm{R}$ & 3 & & & & & & & \\
\hline & 8 & & & & & & & & \\
\hline & $\mathrm{R}$ & & & & 25.8 & & & 5.7 & 37. \\
\hline (mg & $\mathrm{C} \mathrm{Sd}$ & 2 & & & & & & & \\
\hline & $\mathrm{R}$ & & & & .0 & & & & \\
\hline & $\pm \mathrm{Sc}$ & & & & & & & & \\
\hline$Y$, & $\mathrm{R}$ & & & & & & & & \\
\hline & $\mathrm{M} \pm \mathrm{Sd}$ & $14.3 \pm$ & 14.2 & 15.1 & 14.6 & 13.7 & 16.2 & 1.7 & 2.08 \\
\hline $\mathrm{Na}$ & $\mathrm{R}$ & $39.7-$ & 47.8 & 41 & $44.4-45.8$ & 38.6 & $31.2-32.8$ & 92.1 & 98.2 \\
\hline$(\mathrm{mg} / \mathrm{L})$ & $\mathrm{M} \pm \mathrm{Sd}$ & $40.3=$ & 53 & 41. & 45 & 38.8 & 31.9 & 93.8 & 99. \\
\hline & $\mathrm{R}$ & 2 & 2.8 & 2 & .8 & .5 & 51 & 53- & 65 \\
\hline & $1 \pm \mathrm{Sc}$ & & & & & & & $54.5 \pm 1.29$ & $67 \pm 1.82$ \\
\hline $\mathrm{SO}_{4}$ & $\mathrm{R}$ & $637-654$ & $465-466$ & $320-329$ & $198-200$ & $248-251$ & $188-234$ & $207-211$ & $308-312$ \\
\hline & $\Lambda \pm \mathrm{Sc}$ & & $465.7 \pm 0.29$ & $325 \pm 4.82$ & $199 \pm 1.03$ & $249 \pm 1.06$ & $205 \pm 20.8$ & $208 \pm 1.7$ & $310 \pm 1.82$ \\
\hline $\mathrm{TN}$ & $\mathrm{R}$ & $3.56-4.2$ & $2.28-5.7$ & $2.66-4.1$ & $1.9-5.3$ & $2.16-4.9$ & $3.01-7.6$ & $3.76-4.9$ & $3.2-4$ \\
\hline & $\mathrm{M} \pm \mathrm{Sc}$ & & & & & & & 4.1 & \\
\hline & $\mathrm{R}$ & & & & & $0.14-4.47$ & & & $0.13-3.38$ \\
\hline & $\mathrm{M} \pm \mathrm{S}$ & $1.14 \pm 2.01$ & $1.46 \pm 2.67$ & $1.14 \pm 1.9$ & $1.38 \pm 2.37$ & $1.29 \pm 2.11$ & $0.85 \pm 1.16$ & $1.32 \pm 1.8$ & $1.12 \pm 1.53$ \\
\hline
\end{tabular}


Table 4. Relationships between physicochemical parameters in Lake Bafa

\begin{tabular}{|c|c|c|c|c|c|c|c|c|c|c|c|c|c|c|c|c|c|c|c|c|c|c|}
\hline & Atm & $\mathbf{T}^{\circ} \mathbf{C}$ & $\mathrm{pH}$ & EC & TDS & Salinity & $\mathrm{TU}$ & DO & $\begin{array}{c}\text { Sat. } \\
\mathbf{O}_{2}\end{array}$ & BOD & COD & $\begin{array}{c}\mathbf{N H}_{\mathbf{4}^{-}} \\
\mathbf{N}\end{array}$ & $\mathrm{NO}_{2}-\mathrm{N}$ & $\begin{array}{c}\mathrm{NO}_{3^{-}} \\
\mathbf{N}\end{array}$ & $\mathrm{Ca}$ & Mg & $\mathbf{K}$ & $\mathrm{Na}$ & $\mathrm{Cl}^{-}$ & $\mathbf{S O}_{4}$ & $\mathbf{T N}$ & TP \\
\hline Atm & 1 & 0.59 & 0.11 & -.101 & 0.518 & -0.325 & 0.187 & $.925 * *$ & 0.333 & -0.324 & -.103 & 0.356 & -0.366 & -0.224 & -0.191 & -339 & -.022 & 0.183 & -0.232 & -.108 & -0.24 & -0.309 \\
\hline $\mathbf{T}^{\circ} \mathbf{C}$ & & 1 & -0.34 & -.546 & -.121 & -0.656 & -.533 & $-.774 *$ & -.048 & $-.786^{*}$ & -.521 & 0.13 & $-860^{* * *}$ & -0.583 & -0.701 & -396 & -.529 & -.253 & $-.725 *$ & 0.236 & -0.52 & -0.223 \\
\hline pH & & & 1 & 0.471 & $.823 *$ & 0.413 & 0.572 & \begin{tabular}{|c|}
-0.001 \\
\end{tabular} & -.135 & 0.451 & 0.166 & 0.628 & $\begin{array}{ll}0.196 \\
\end{array}$ & -0.025 & 0.147 & 0.15 & 0.271 & 0.64 & 0.496 & -.192 & 0.037 & 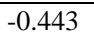 \\
\hline $\mathbf{E C}$ & & & & 1 & 0.31 & 0.358 & 0.611 & \begin{tabular}{l|l}
-0.108 \\
\end{tabular} & 0.476 & 0.251 & -.026 & 0.364 & 0.602 & 0.402 & 0.61 & 0.329 & 0.635 & 0.202 & 0.535 & 0.251 & 0.579 & 0.144 \\
\hline TDS & & & & & 1 & 0.171 & 0.532 & 0.364 & $\begin{array}{l}-.055 \\
\end{array}$ & 0.247 & 0.213 & 0.447 & 0.011 & -0.075 & 0.017 & 0.138 & 0.17 & .714* & 0.345 & -.131 & -0.068 & -0.508 \\
\hline Salinity & & & & & & 1 & 0.673 & -0.423 & 0.197 & $.911^{* *}$ & 0.673 & 0.432 & $.742^{*}$ & $.708^{*}$ & $.775^{*}$ & 0.401 & $.729 *$ & 0.537 & $.922^{* * *}$ & -.615 & 0.486 & 0.251 \\
\hline TU & & & & & & & 1 & -0.038 & 0.628 & 0.686 & 0.293 & 0.593 & $\begin{array}{l}.757^{*} \\
\end{array}$ & $\begin{array}{l}.732^{*} \\
\end{array}$ & $.805^{*}$ & -.056 & 0.592 & 0.338 & 0.664 & -.539 & 0.706 & 0.315 \\
\hline DO & & & & & & & & 1 & 0.263 & -0.552 & -.262 & 0.367 & $\begin{array}{c}-0.561 \\
\end{array}$ & -0.35 & -0.345 & $\begin{array}{l}-201 \\
\end{array}$ & -.078 & 0.142 & -0.329 & 0.153 & -0.32 & -0.318 \\
\hline Sat. $\mathbf{O}_{2}$ & & & & & & & & & 1 & 0.085 & -.162 & 0.388 & 0.516 & $\begin{array}{ll}0.678 \\
\end{array}$ & 0.676 & -327 & 0.415 & -0.28 & 0.146 & -.205 & $.746 *$ & 0.667 \\
\hline BOD & & & & & & & & & & 1 & $.750^{*}$ & 0.231 & $.791^{*}$ & $\begin{array}{ll}0.648 \\
\end{array}$ & $.734^{*}$ & 0.248 & 0.604 & 0.48 & $.849^{* * *}$ & $-736^{*}$ & 0.412 & 0.166 \\
\hline COD & & & & & & & & & & & 1 & -.105 & 0.446 & 0.314 & 0.443 & 0.556 & 0.636 & 0.687 & $.761 *$ & -.546 & -0.076 & -0.201 \\
\hline $\mathbf{N H}_{4}-\mathbf{N}$ & & & & & & & & & & & & 1 & 0.116 & 0.202 & 0.274 & -.151 & 0.327 & 0.328 & 0.33 & -.325 & 0.26 & -0.002 \\
\hline $\mathbf{N O}_{2}-\mathbf{N}$ & & & & & & & & & & & & & 1 & $.858^{* *}$ & $.956^{* * *}$ & 0.152 & 0.684 & 0.09 & $.727^{*}$ & -0.44 & $.781 *$ & 0.534 \\
\hline $\mathrm{NO}_{3}-\mathrm{N}$ & & & & & & & & & & & & & & 1 & $.909 * *$ & 0.045 & 0.526 & 0.004 & 0.592 & -.482 & $.903^{* * *}$ & $.795^{*}$ \\
\hline $\mathbf{C a}$ & & & & & & & & & & & & & & & 1 & 0.157 & $.785^{*}$ & 0.139 & $.751^{*}$ & -.469 & $.803 *$ & 0.574 \\
\hline Mg & & & & & & & & & & & & & & & & 1 & 0.538 & 0.673 & 0.627 & 0.305 & -0.108 & -0.29 \\
\hline $\mathbf{K}$ & & & & & & & & & & & & & & & & & 1 & 0.521 & $.863^{* * *}$ & -.264 & 0.344 & 0.052 \\
\hline $\mathrm{Na}$ & & & & & & & & & & & & & & & & & & 1 & $.713^{*}$ & -.202 & -0.216 & -0.556 \\
\hline $\mathrm{Cl}^{-}$ & & & & & & & & & & & & & & & & & & & 1 & -.406 & 0.378 & 0.031 \\
\hline $\mathrm{SO}_{4}$ & & & & & & & & & & & & & & & & & & & & 1 & -0.209 & -0.201 \\
\hline TN & & & & & & & & & & & & & & & & & & & & & 1 & $.847 * *$ \\
\hline TP & & & & & & & & & & & & & & & & & & & & & & 1 \\
\hline
\end{tabular}

** Correlation is significant at the 0.01 level (2-tailed)

* Correlation is significant at the 0.05 level (2-tailed) 
Principal Component Analysis (PCA) and Cluster Analysis (CA)

In this study, the stations were the classified dependent variables. On the other hand, all the measured components created as independent variables. The PCA was applied on 22 physicochemical parameters for Lake Bafa with 8 sampling stations to determine variation in water quality during two years period. The obtained results of the Kaiser-Meyer-Olkin (KMO) Sample Proficiency Test were calculated as 0.803 and show that the sample size is quite good and sufficient. In this study, the eigenvalues are greater than 1 at the PCA 1 (43\% variance), PCA 2 (20.05\% variance) and
PCA 3 (16\% variance). The biplots, which are the graphical representation of factor loadings in different components (PCA 1, PCA 2 and PCA 3) are given in Figure 2, 3 and 4. Eigenvalues greater than one are selected as criteria for the evaluation of basic components as the sources of variance that should be explained from the data used. Data that are not correlated or have low correlation coefficient are not evaluated in order to increase the reliability of PCA analysis. The PCA analysis led to the explanation of $79.05 \%$ total variance in case of Lake Bafa. Scree Plot in which the eigenvalues of the basic components are expressed is given in Figure 5.

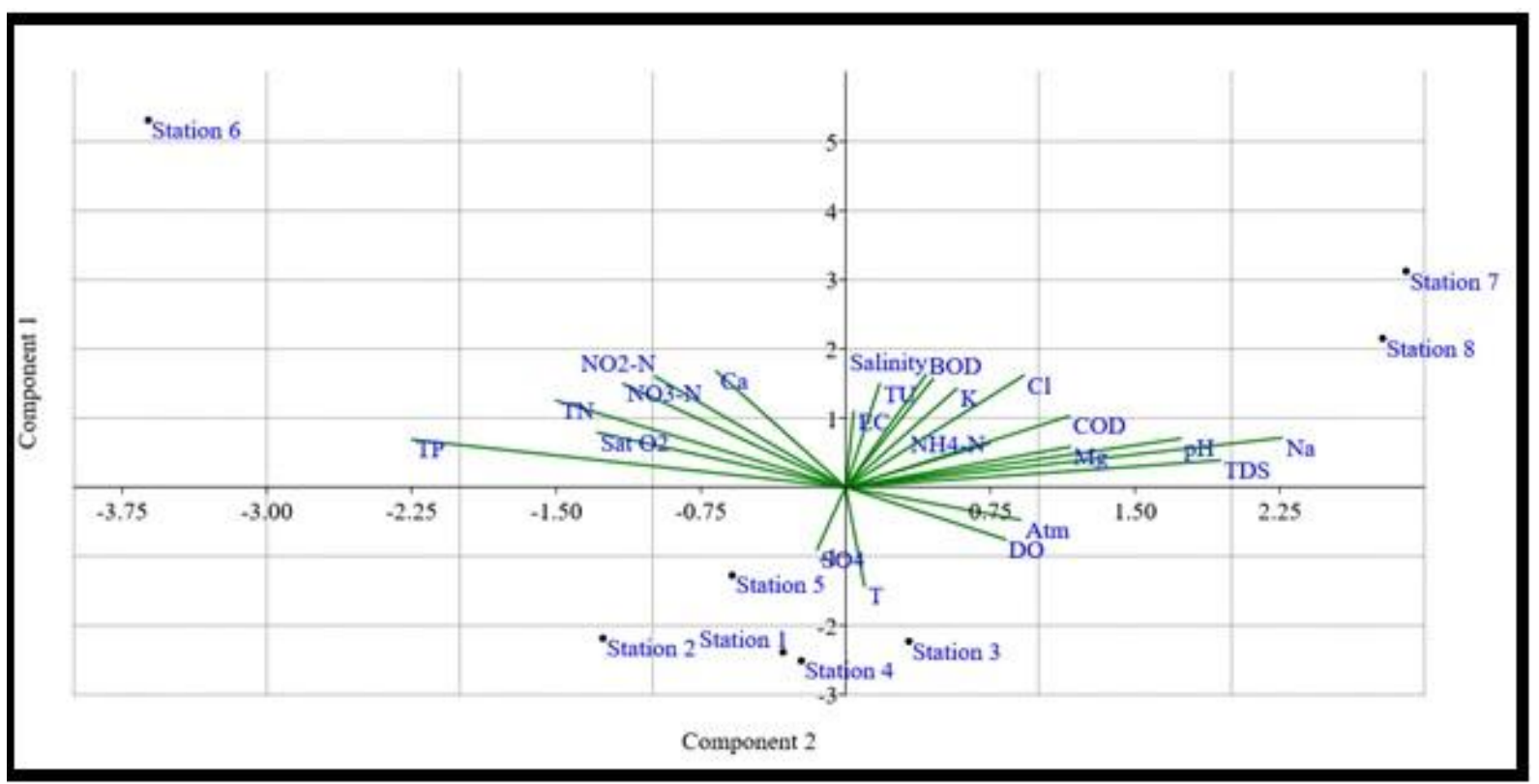

Figure 2. Biplots for Principal component analysis PCA 1 - PCA 2 component of water quality in Lake Bafa

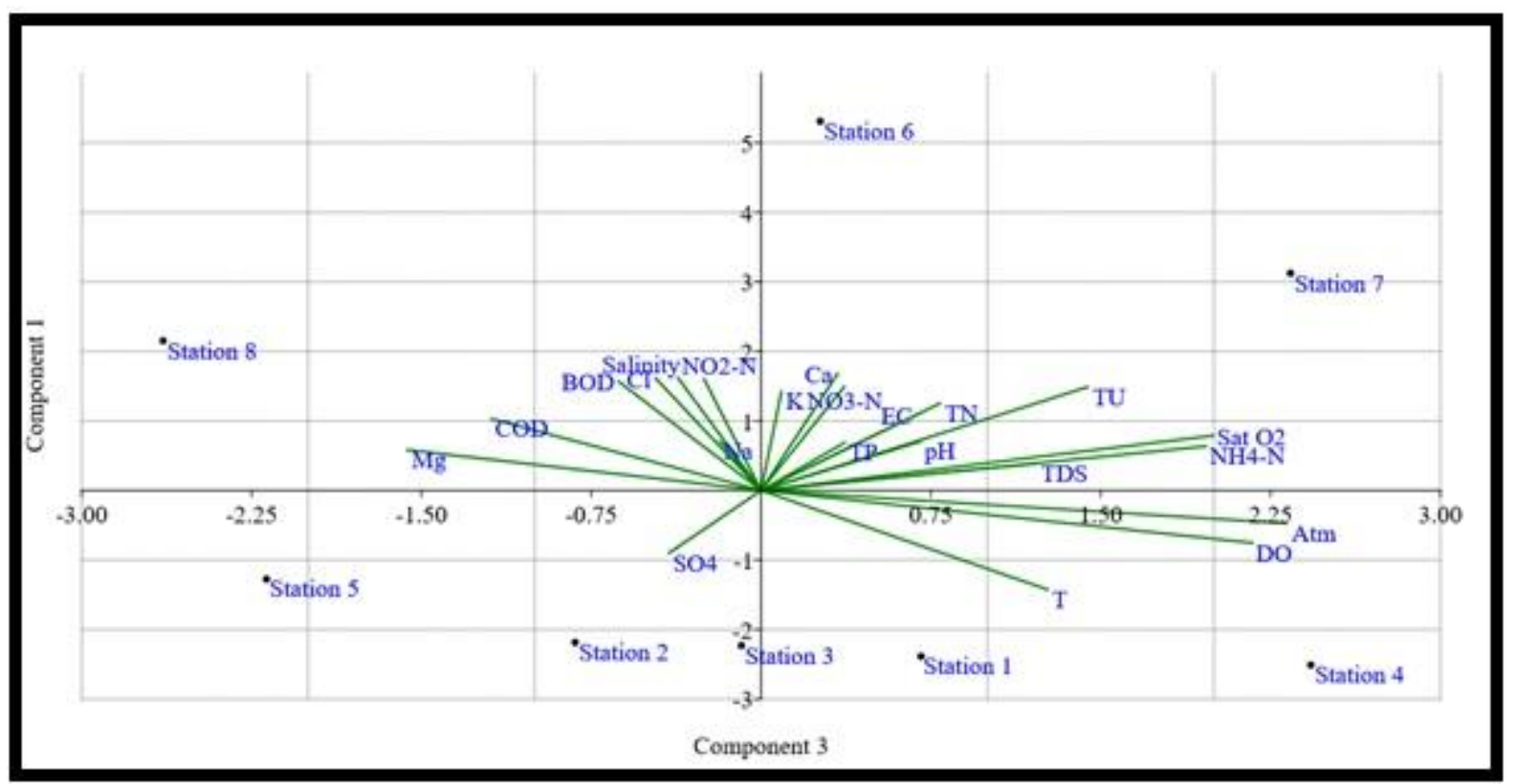

Figure 3. Biplots for Principal component analysis PCA 1 - PCA 3 component of water quality in Lake Bafa 


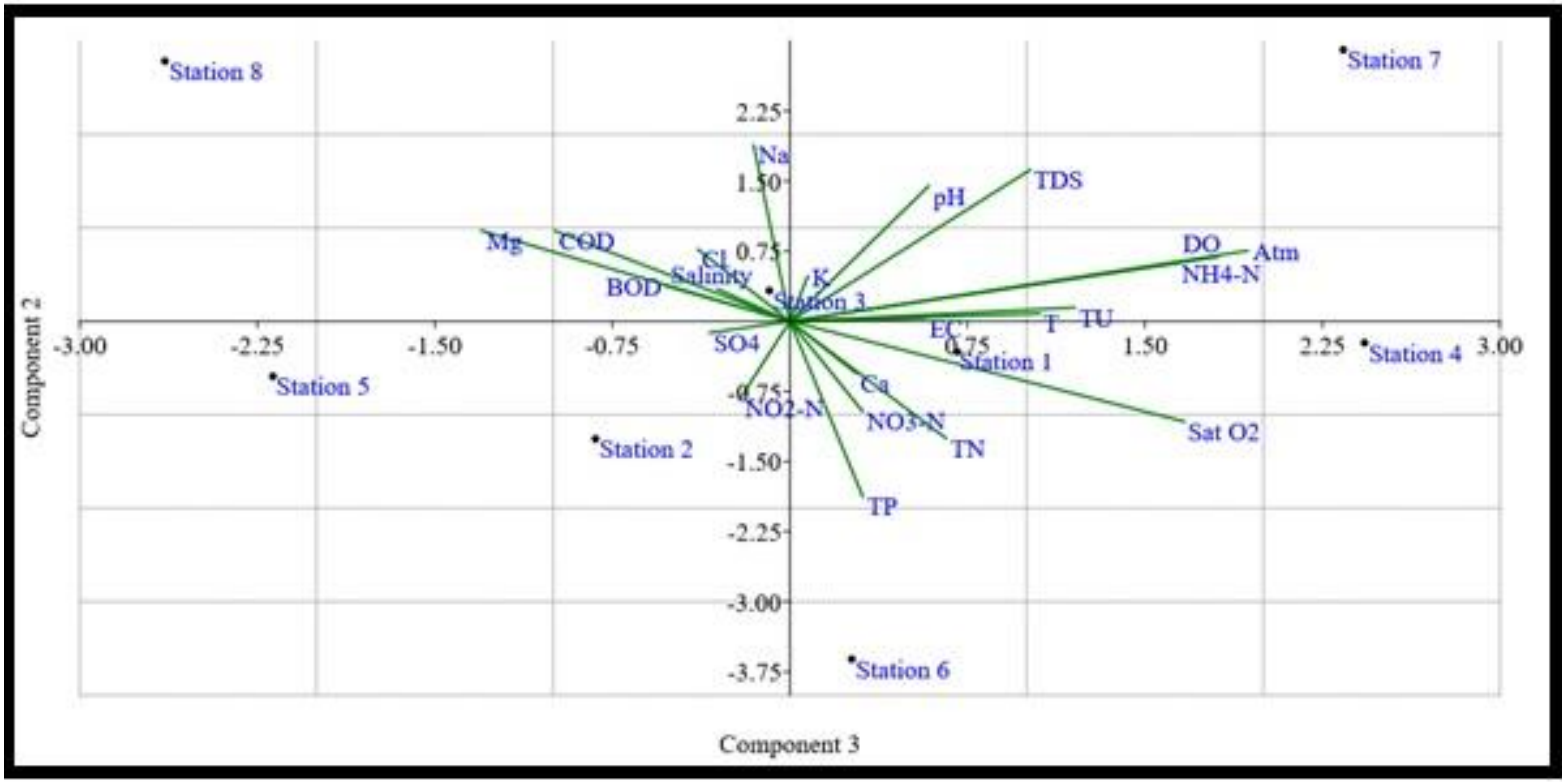

Figure 4. Biplots for Principal component analysis PCA 2 - PCA 3 component of water quality in Lake Bafa

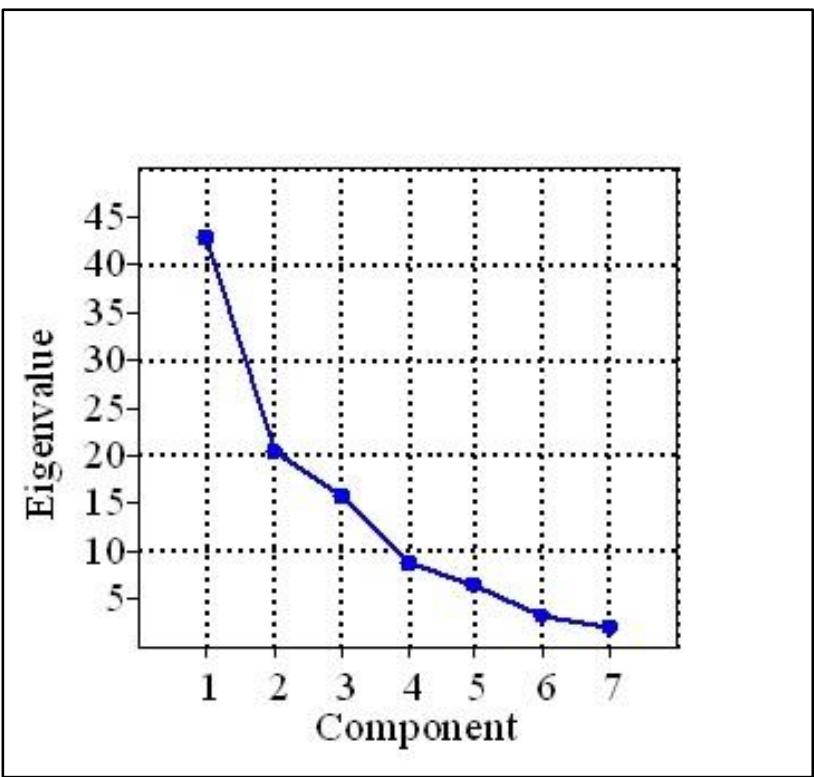

Figure 5. Scree Plot diagram

In this research, CA was applied on lake parameters to determine spatial similarity and dissimilarity for classifying of stations. The resulted dendrogram (Figure 6) grouped all the eight sampling stations into four statistically significant clusters as station (1-2), (3-4), (6-7) have low mutual dissimilarities as compared to $8^{\text {th }}$ station. On the other hand, the highest similarity was identified in the $3^{\text {rd }}$ and $4^{\text {th }}$ station while the lowest similarity was identified in the $1^{\text {st }}$ and $8^{\text {th }}$ station.

According to Klee (1991), the water quality class at $1^{\text {th }}$ and $2^{\text {nd }}$ stations are beta-alphamesosaprob (Class II-III) in summer and autumn while the water quality class is betamesosaprob (Class II) in winter and the water quality class is alphamesosaprob (Class III) in spring. The $3^{\text {rd }}$ and $4^{\text {th }}$ stations are alphamesosaprob (Class III) in summer and autumn while the water quality is beta-alphamesosaprob (Class II-III) in winter and spring. The $6^{\text {th }}$ and $7^{\text {th }}$ stations are alpha-polysaprob (Class III-IV) in all season. The $8^{\text {th }}$ station is alphamesosaprob (Class III) in all season.

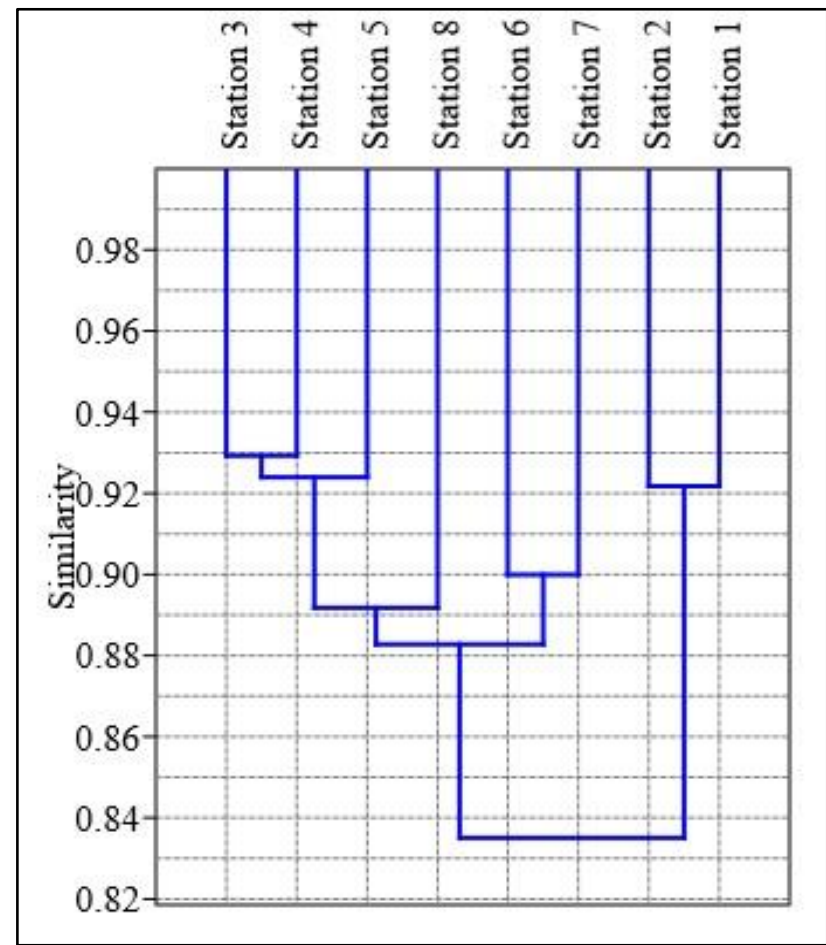

Figure 6. Classification of stations based on similarities of physicochemical parameters.

\section{Discussion}

$\mathrm{T}^{\circ} \mathrm{C}$ is a very important parameter for aquatic life, as it changes the viscosity and density of water, affects the rate of biochemical reactions occurring in the aquatic environment and the solubility of gases. It is known that the metabolism of organisms, 
especially fish, varies with temperature. For example, carp is euriterm but begins feeding $\left(8-10^{\circ} \mathrm{C}\right)$ and breeding $\left(15^{\circ} \mathrm{C}\right)$ only after certain temperatures (Nikolsky 1963). The most suitable water temperature for trouts is $8-16^{\circ} \mathrm{C}$. According to the WPCR, Lake Bafa had class II-III water quality in terms of $\mathrm{T}^{\circ} \mathrm{C}$.

DO and Sat. $\mathrm{O}_{2}$, which is vital for aquatic organisms, varies depending on the temperature as well as the photosynthesis rate of plants and the trophic level of the lakes. The oxygen holding capacity of water is affected by temperature, pressure and salts dissolved in water. It is desired that the fish grown waters are saturated with oxygen. Bremond and Vuichard (1973) stated that the minimum amount of DO required for the cyprinid species to survive should be $5.0 \mathrm{mg} / \mathrm{L}$. For trouts, the oxygen of the water should be at least $7.0 \mathrm{mg} / \mathrm{L}$ (Özdemir 1994). According to the WPCR, Lake Bafa has been found to have class II water quality in terms of DO and Sat. $\mathrm{O}_{2}$ parameters, excluding the $1^{\text {st }}$ and $2^{\text {nd }}$ stations. The rest of the stations of Lake Bafa are described as "Contaminated Regions".

According to Balık and Ustaoğlu (1989); Cirik and Metin (1989); Sarı et al. (2001); Öztürk et al. (2002); Demir (2007); Koç (2008); Kazanc1 et al. (2008); Yabanlı et al. (2011); Erdoğan (2011); Kesici et al. (2012), the $\mathrm{T}^{\circ} \mathrm{C}$ values varied between 8.0- $31.6^{\circ} \mathrm{C}$ in Lake Bafa while DO varied between 4.45-7.97 mg/L. According to Kesici et al. (2012), the average oxygen saturation value varied between $37 \%-79 \%$ in Lake Bafa.

$\mathrm{pH}$, which is an indicator of the acidity of water, is one of the important factors affecting the life. In lake waters that are not contaminated in any way, the $\mathrm{pH}$ value varies between 6.0 and 9.0. While many fish species show good growth in waters with a $\mathrm{pH}$ of 6.5-8.5 (Arrignon 1976; Dauba 1981), waters with a $\mathrm{pH}$ higher than 10.8 and less than 5.0 have a lethal effect for the Cyprinidae (especially carp) (Svobodá et al. 1993). Generally, alkaline waters are more suitable for trout production. Although trout can live in waters with a $\mathrm{pH}$ between $4.5-10$, the best are waters with a pH of 7.5-8.0 (Özdemir 1994). The waters of the stations detected on Lake Bafa have a slightly alkaline character in terms of $\mathrm{pH}$ values and all stations have class I-II water quality in terms of $\mathrm{pH}$ according to the WPCR. For Cyprinid health, the mandatory $\mathrm{pH}$ range in waters is expected to be $6.00-9.00$ (EC 2006). According to the $\mathrm{pH}$ data determined in the region, there is no risk for Cyprinid species. In addition, it has been determined that the $\mathrm{pH}$ values of the watershed waters do not exceed the 6.5-9.5 range reported for $\mathrm{pH}$ in the Turkish Standards Institute's watershed notification (TS266 2005). According to Kesici et al. (2012), the average
$\mathrm{pH}$ values were changing between 6.89 and 9.12 in Lake Bafa.

The EC of waters is a measure of the amount of salts or soluble substances in the water and depends on both geological and external factors (Höll 1979). According to the WPCR, the Lake Bafa has a Class III water quality in terms of the determined EC values.

TDS originate from natural resources, domestic and industrial wastewater and agricultural areas. The main ions that contribute to the total amount of dissolved solids are carbonate, bicarbonate, chloride, sulfate, nitrate, sodium, potassium, calcium, magnesium, etc. In addition, silt, clay, small particles of organic structure, inorganic substances, organic compounds that can be dissolved, plankton and other microscopic organisms compose TDS. The amount of TDS affects the properties of drinking water such as taste, hardness and corrosion. According to the WPCR, the Lake Bafa has a Class III water quality in terms of the determined TDS values.

Turbidity is seen in waters containing suspended solids, which prevent the passage of light. Turbidity can be caused by many organic or inorganic substances. Turbidity is important for 3 reasons in terms of environment. First; the aesthetic use is avoided, the second is the low filterability and finally the disinfectability is not effective. It is recommended not to exceed 1 NTU (turbidity unit) by EPA and world health organization (WHO). According to the WPCR, $6^{\text {th }}$ and $7^{\text {th }}$ stations in Lake Bafa has a Class IV water quality in terms of the determined TU values.

According to the TWPCR (2008), the $\mathrm{NH}_{4}-\mathrm{N}$ concentration $<0.2 \mathrm{mg} / \mathrm{L}$ is Class $\mathrm{I}$; between $0.2-1 \mathrm{mg} / \mathrm{L}$ is Class II; between $1-2 \mathrm{mg} / \mathrm{L}$ is Class III; and the waters around $2 \mathrm{mg} / \mathrm{L}$ are specified as Class IV quality waters. In Lake Bafa, the water quality is Class II according to $\mathrm{NH}_{4}-\mathrm{N}$ values. In Lake Bafa, $\mathrm{NH}_{4}-\mathrm{N}$ values are in parallel with Küçüksu Pond (Kastamonu) (Mutlu and Aydın Uncumusaoğlu 2017).

The $\mathrm{NO}_{3}-\mathrm{N}$ in groundwater and surface waters results from the oxidation of ammonia, which occurs as a result of the decomposition of proteins contained in vegetable and animal wastes, and nitrate fertilizers used in agricultural areas. $\mathrm{NO}_{3}-\mathrm{N}$ is the most common form of nitrogen in freshwaters, and it is very rare in uncontaminated waters (Wetzel 2001; Manahan 2011). It is also below the limit value reported as $50 \mathrm{mg} / \mathrm{L}$ in World Health Organization, European Union and TS266, where the $\mathrm{NO}_{3}-\mathrm{N}$ values determined at all stations examined in the Lake Bafa are below the recommended $10 \mathrm{mg} / \mathrm{L}$ limit value in healthy waters reported by EPA. (EPA 1979; TS266 2005; EC 2007; WHO 2011). 
$\mathrm{NO}_{2}-\mathrm{N}$ is an intermediate product in biological oxidation from ammonium to nitrate and can reach very high levels, especially in organically contaminated waters, where oxygen is not sufficient (Egemen and Sunlu 1999). According to the drinking water standards reported by the WHO, it is expected that the $\mathrm{NO}_{2}-\mathrm{N}$ value in the waters will not exceed the $0.2 \mathrm{mg} / \mathrm{L}$ limit (WHO 2011). According to the EC directive reported by the European Commission, the $\mathrm{NO}_{2}-\mathrm{N}$ concentration in waters is expected not to exceed the $0.03 \mathrm{mg} / \mathrm{L}$ limit in terms of Cyprinid health (EC 2006). Accordingly, $\mathrm{NO}_{2}-\mathrm{N}$ concentrations detected in Lake Bafa almost pose a risk to Cyprinid health. Lake Bafa is exposed to sewage waste of many settlements and there are many agricultural land around it. As it is known, the most important sources of $\mathrm{NO}_{2}-\mathrm{N}$ in waters include organic substances, nitrogenous fertilizers and some minerals (Wetzel 2001; Manahan 2011). The very high nitrite values detected in the waters of the region show that the wastes of the settlements are discharged into the system without any or sufficient purification and that agricultural fertilizers used in the basin are an ecologically important source of stress.

According to the TWPCR (2008), the $\mathrm{NO}_{2}-\mathrm{N}$ concentration $<0.002 \mathrm{mg} / \mathrm{L}$ is Class $\mathrm{I}$; between $0.002-0.01 \mathrm{mg} / \mathrm{L}$ is Class II; between $0.01-0.05 \mathrm{mg} / \mathrm{L}$ is Class III; 0.05> is stated as water in Class IV quality. In our study, Lake Bafa water quality class in all stations was found to be slightly polluted as Class III. In Lake Bafa, $\mathrm{NO}_{2}-\mathrm{N}$ values are in parallel with Eğirdir Lake (Zeybek et al. 2012).

Phosphorus in ground and surface waters depends on population density, agricultural fertilization methods and fertilization frequency, and vegetation and soil structure are also significantly influenced by phosphorus accumulation in waters. In addition, it has been reported that detergents used in cleaning and reaching the receiving water environment with wastewater are factors affecting phosphorus concentration (Uslu and Türkman 1987). It has been calculated that $91 \%$ of phosphate comes from domestic and industrial wastewater and 9\% from agricultural areas to receiving waters (Egemen and Sunlu 1999). According to the classification reported by Uslu and Türkman based on phosphate concentrations in waters; waters with phosphate concentrations up to $0.02 \mathrm{mg} / \mathrm{L}$ is Class I, waters up to $0.16 \mathrm{mg} / \mathrm{L}$ Class II, waters up to $0.65 \mathrm{mg} / \mathrm{L}$ Class III, water higher than $0.65 \mathrm{mg} / \mathrm{L}$ has class IV water quality (Uslu and Türkman 1987). According to the WPCR, Lake Bafa has a Class III-IV water quality in terms of the determined TP values. In Lake Bafa, TP values are in parallel with Küçüksu Pond (Kastamonu) (Mutlu and Aydın Uncumusaoğlu 2017).
The ecological importance of $\mathrm{SO}_{4}$ in natural waters is quite large and it must be present in the environment in order to increase the biological efficiency especially for plant growth. In case of deficiency, the development of phytoplankton in the environment is adversely affected and this decreases primary productivity (Atıc1 and Obalı 1999; Tanyolaç 2004). According to the WPCR, Lake Bafa has a Class IV water quality in terms of the determined $\mathrm{SO}_{4}$ values. In addition, sulfate values determined in the waters of the region were determined to be lower than the limit value of 250 $\mathrm{mg} / \mathrm{L}$ reported in TS266 and EC criteria (TS266 2005; EC 2007).

According to Tanyolac (2004), oxygen concentration in aquatic system is a very important subject, as the biological, chemical and physical processes involved in the increase or decrease of oxygen in lake. The highest value of BOD was obtained at the stations $5^{\text {th }}, 6^{\text {th }}, 7^{\text {th }}$ and $8^{\text {th }}$. The highest value of COD was recorded at $8^{\text {th }}$ station. COD is often used for determining waste concentration and is applied primarily pollutant mixture such as industrial, agricultural and farming waste. Our results consistent with Büyük Menderes River carries high amounts of nitrogen because of anthropogenic activities such as fertilizers and pesticide usage, organic contaminants flow of water. Because of this reason, chloride, total nitrogen and phosphate concentrations are affected and exceeded the drinking water limits of WHO legislation.

Because of important amounts of dissolved salt, the high level of EC, TDS and salinity values was observed in $6^{\text {th }}$ and $7^{\text {th }}$ station of lake on summer season. At the reason of high conductivity, TDS and salinity in dry season, represent the water with high electrolyte concentration because of the evaporatation. Kazi et al. (2009) and Zhao et al. (2012) obtained similar results in Manchar and Baiyangdian Lake. Zacheus and Martikainen (1997) submitted that significant amounts of main cations like $\mathrm{Na}^{+2}, \mathrm{Ca}^{+2}$ and $\mathrm{Mg}^{+2}$ concentration.

In this study, evaluation of the parameters affecting the water quality of Lake Bafa was determined by multivariate statistical techniques. Despite the use of multivariate statistical analysis are often used to determine the water quality of lakes and rivers throughout the world, there are not many studies in Turkey. PCA is a statistical identification pattern which is a dimension- reduction method that can be used to diminish large data set of variables to a small data set at the same time (Helena et al. 2000; Alberto et al. 2001; Kazi et al. 2009; Zhao et al. 2012). According to the Pearson Correlation analysis results applied to the data, strong positive correlations were recorded between TDS and EC data 
$(p<0.01)$ in Lake Bafa. Another strong positive correlations were recorded between $\mathrm{DO}$ and $\mathrm{T}^{\circ} \mathrm{C}$ $(p<0.01)$ in Lake Bafa. Positive loading on Sat. $\mathrm{O}_{2}$, TDS and EC has been related with domestic and agricultural runoff. According to Solanki et al. (2010), the significant relationship between $\mathrm{T}^{\circ} \mathrm{C}$ and DO is a natural process in lakes. Iscen et al. (2008) were used to multivariate statistical techniques such as PCA in order to determine surface water quality in Uluabat Lake. According to results in Ulubat Lake, it may be concluded that of the $77.35 \%$ of variances explained by the Total Coliform, Fecal Coliform, $\mathrm{PO}_{4}^{3}{ }_{4} \mathrm{P}, \mathrm{COD}, \mathrm{SO}_{4}^{3}$ and $\mathrm{T}^{\circ} \mathrm{C}$. Duran (2006) was used PCA analysis to determine the effect of physicochemical parameters on benthic invertebrates in a study conducted in Behzat Stream. As a result of his study, he obtained two principal components that collectively explained $78.148 \%$ of the variance which was influenced by abundance hardness, DO, $\mathrm{NH}_{4}-\mathrm{N}, \quad \mathrm{NO}_{3}-\mathrm{N}, \quad \mathrm{PO}_{4}-\mathrm{P}, \quad \mathrm{NO}_{2}-\mathrm{N}$ and $\mathrm{COD}$ concentrations. Duran and Akyıldız (2011) used PCA technique to assess the effect of physicochemical parameters in Süleymanlı Lake. According to Shrestha and Kazama (2007) andNajar and Khan (2012), if eigenvalues are greater than 1, it is considered significant and is taken as criterion for analysis of principal components required to explain the variance in the data. According to Liu et al. (2003), the factor loadings classified as "strong", "moderate" and "weak" corresponding to precise loading values of $>0.75,0.75-0.50$ and $0.50-0.30$, respectively. In their study, they obtained $78.148 \%$ of the variance which was positively correlated the $\mathrm{pH}$ and the $\mathrm{T}^{\circ} \mathrm{C}$ while negatively correlated the $\mathrm{EC}, \mathrm{DO}$, TDS and orthophosphate as a result of PCA analysis. According to the results of PCA applied to physicochemical data in Pazarsuyu Stream, PCA indicates the six components responsible for the data structure, accounting for $82.88 \%$ of the total variance of the dataset (Ustaoğlu and Tepe 2019). According to the results of PCA applied to physicochemical data in Tuzakl1 Pond, PCA indicates the four main components (soluble salts, ammonium and phosphorus) responsible for the data structure, accounting for $88.31 \%$ of the total variance of the dataset (Uncumusaoğlu and Mutlu 2019). According to the results of PCA applied to physicochemical data in Ergene River basin, the strong negative correlations were recorded between DO, salinity, TDS and EC (Tokatli 2020).

Besides its ecological, historical and economical importance, Lake Bafa was chosen as a study area since Büyük Menderes basin served as one of the pilot basins for WFD applications in Turkey. Monoculture agricultural practices in the region impoverish the soil in terms of many minerals. In order to overcome this deficiency, inorganic and phosphate fertilizers are used extensively in almost all basin soils. The major reason of corruption to the Lake Bafa is recorded to be the flow of industrial, agricultural and domestic waste from the upstream part of Büyük Menderes River, and pollution from local fisheries around te lake. The data obtained from the statistical analysis clearly reveals the negative effects of agricultural and industrial pollution on the system. To improve the quality of Lake Bafa, one of the most important fresh waters of the Aegean region, to reduce stress and pressure on aquatic organisms and to protect the health of the local people;

-Unconscious use of chemical, fertilizers and pesticides should be prevented,

-Industrial establishments located in the basin should be inspected frequently and prevented from giving their wastes to the system without treatment,

-In addition, the water quality of the lake should be monitored continuously, by means of physicochemical and biological ways, and should be able to intervene quickly if necessary.

We believe that this study will constitute vital perspective to the monitoring of lakes data.

\section{Acknowledgements}

This research was supported by Scientific and Technological Research Council of Turkey (TUBITAK, Project no: 114Y249).

\section{References}

Akkan T, Yazicioglu O, Yazici R, Yilmaz M. 2018. Assessment of irrigation water quality of Turkey using multivariate statistical techniques and water quality index: Siddıklı Dam Lake. Desalin Water Treat. 115:261.

doi: $10.5004 /$ dwt.2018.22302

Alberto WD, Del Pilar DM, Valeria AM, Fabiana PS, Cecilia HA, De Los Angeles BM. 2001. Pattern recognition techniques for the evaluation of spatial and temporal variations in water quality. A case study: Suquia River basin (Cordoba-Argentina). Water Resour. 35:2881-94.

doi: 10.1016/s0043-1354(00)00592-3

Arrignon J. 1976. Aménagement Ecologique et Piscicole des Eaux Douces. Bordas, Paris, 322 p.

Atıcı T, Obalı O. 1999. Susuz Göleti (Ankara) algleri ve su kalite değerlendirmesi. Gazi Üniviversitesi Gazi Eğitim Fakültesi Dergisi. 19(3):99-104.[in Turkish]

Balık S. Ustaoglu MR. 1989. Bafa Gölündeki Ulubat Balig1 (Acanthobrama mirabilis Ladiges, 1960)'nin biyoekolojik ve ekonomik yönlerden incelenmesi. Turkish J Zool. 13(3):141-174. [in Turkish]

Balık S, Ustaoglu MR, Sarı HM. 1992. Bafa Gölü (SökeAydin) Kababurun (Chondrostoma nasus L., 1758) populasyonunun biyolojik özelliklerinin incelenmesi. Firat Universitesi XI. Ulusal Biyoloji Kongresi. 4958, Elazı̆g. [in Turkish] 
Balık S. 1995. Freshwater Fish in Anatolia, Turkey. Biological Conservation. 72: 213-223.

Bremond R, Vuichard R. 1973. Parameters de la qualite des eaux: Ministere de la Protection de la Nature et de Environnement, Documentation, Française, Paris, $179 \mathrm{p}$.

Cirik S, Metin C. 1989. Planktonic algae and the seasonal changes of Lake Bafa (in Turkish). Enviroment Symposium. 604-613, Adana.

Dauba F. 1981. Etude comperative de la fauna des poissons dans les ecosystemes de deux reservoirs: Luzech (Lut) et Chastang (Dordogone): These de troisieme cycle L'Institut National Polytechnique de Toulouse. 179 p.

Demir N. 2007. Changes in the phytoplankton community of a coastal, hyposaline lake in western Anatolia, Turkey. Limnology. 8, 337-342. doi: 10.1007/s10201-007-0214-4

Duran M. 2006. Monitoring water quality using benthic macroinvertebrates and physicochemical parameters of Behzat Stream in Turkey. Polish JEnviron Stud. 15(5):709-717.

Duran M, Akyildiz GK. 2011. Evaluating benthic macroinvertebrate fauna and water quality of Suleymanli Lake (Buldan-Denizli) in Turkey. Acta Zool Bulgar. 63(2):169- 178.

Dügel M, Kazanc1 N. 2004. Assessment of water quality of the Büyük Menderes River (Turkey) by using ordination and classification of macroinvertebrates and environmental variables. J Freshwater Ecol. 19(4):605-612.

doi: 10.1080/02705060.2004.9664741

EC (European Communities). 2006. EC of the European Parliament and of the council of 6 September 2006 on the quality of fresh waters needing protection or improvement in order to support fish life. Directive 2006/44.

EC (European Communities). 2007. European communities (drinking water) (no. 2). Regulations 2007, S.I. No. 278 of 2007.

Egemen O, Sunlu U. 1999. Water quality. Ege University Fisheries Faculty Issue number: 14, İzmir. ISBN: 9754831416.

Elvira B. 1987. Taxonomic revision of the genus Chondrostoma Agassiz, 1835 (Pisces, Cyprinidae). Cybium 11:111-140.

EPA (United States Environmental Protection Agency). 1979. A review of the EPA red book quality criteria for water. Environmental Protection Agency, USA. $311 \mathrm{p}$.

Erdoğan S. 2011. Fiziksel etkiye kimyasal tepki: Bafa Gölü sulak alan ekosistemi (Türkiye) örneği. Ankara Üniversitesi Çevrebilimleri Dergisi. 3(1):1-8. doi: 10.1501/Csaum_0000000040. [in Turkish]

Helena B, Pardo R, Vega M, Barrado E, Fernandez JM, Fernandez L. 2000. Temporal evolution of groundwater composition in an alluvial aquifer (Pisuerga river, Spain) by principal component analysis. Water Resources. 3:807-16. doi: 10.1016/S0043-1354(99)00225-0
Höll K. 1979. Wasser (untersuchung, beurteilung, aufbereitung, chemie, bakteriologie, virologie, biologie). Berlin: Auflage, de Gruyter 586 p.

Işcen CF, Emiroğlu Ö, Ilhan S, Arslan N, Yilmaz V, Ahiska S. 2008. Application of multivariate statistical techniques in the assessment of surface water quality in Uluabat Lake, Turkey. Environ Monit Assess. 144:269-276. doi: 10.1007/s10661-007-9989-3

Kazanc1 N, Girgin S, Dügel M. 2008. Research on the Limnology of Lake Bafa in South-Western Turkey and climate change impacts. Rewiew of Hydrobiology. 2:207-223.

Kazi TG, Arain MB, Jamali MK, Jalbani N, Afridi HI, Sarfraz RA, Baig JA, Shah AQ. 2009. Assessment of water quality of polluted lake using multivariate statistical techniques: A case study. Ecotoxicology and Environmental Safety. 72:301-309. doi: 10.1016/j.ecoenv.2008.02.024

Kesici K, Tüney Ġ, Kesici E, Sukatar A. 2012. Bafa Gölü̈nde ani alg çoğalmasına neden olan Nodularia spumigena türünün morfolojik tayini. 21. Ulusal Biyoloji Kongresi. 1122-1145, İzmir. [in Turkish]

Klee O. 1991. Angewandte Hydrobiologie.- G. Theieme Verlag, 2. neubearbeitete und erweiterte Auflage, 272, Stuttgart-New York.

Knipping M, Mullenhoff M, Brückner H. 2008. Human induced landscape changes around Bafa Gölü (western Turkey). Veg Hist Archaeobot. 17:365-380. doi:10.1007/s00334-007-0132-8

Koç C. 2008. The effects of the environment and ecology projects on lake management and water quality. Environ Monit Assess. 146:397-409. doi:10.1007/s10661-008-0446-8

Kuru M, Balık S, Ustaoglu MR, Unlu E, Taskavak E, Gul A, Yılmaz M, Sarı HM, Kucuk F, Kutrup B, Hamalosmanoglu M. 2001. Türkiye'de bulunan sulak alanların RAMSAR Sözleşmesi balık kriterlerine gore değerlendirilmesi. Proje Kesin raporu, 55-58. [in Turkish]

Kükrer S, Mutlu E. 2019. Assessment of surface water quality using water quality index and multivariate statistical analyses in Saraydüzü Dam Lake, Turkey. Environ MonitAssess. 191(2):71. doi: 10.1007/s10661-019-7197-6

Liu CW, Lin KH, Kuo YM. 2003. Application of factor analysis in the assessment of groundwater quality in a Blackfoot disease area in Taiwan. Sci Total Environ. 313(1-3): 77-89. doi: 10.1016/s0048-9697(02)00683-6

Manahan SE. 2011. Water chemistry: green science and technology of nature's most renewable resource. Taylor \& Francis Group 398p. doi: 10.1201/b11794

Mermer A. 1989. Gediz Nehrindeki Kababurun Balığ (Chondrostoma nasus Linnaeus, 1758) populasyonunun biyolojik yöndenden incelenmesi. [Yüksek Lisans Tezi]. Ege Üniversitesi. [in Turkish]

Mutlu E, Aydın Uncumusaoğlu A. 2017. Küçüksu Göleti'nin (Taşköprü-Kastamonu) su kalitesinin incelenmesi. Yunus Araştırma Bülteni. 2017(3): 
209-224. doi:10.28955/alinterizbd.332812. [in Turkish].

Najar IA, Khan AB. 2012. Assessment of water quality and identification of pollution sources of three lakes in Kashmir, India, using multivariate analysis. Environ Earth Sci. 66:2367-2378.

doi:10.1007/s12665-011-1458-1

Nikolsky GV. 1963. The Ecology of Fishes (Translated by L. Birkett), Academic Press: London and New York, $352 \mathrm{p}$.

Oczkowski A, Nixon S. 2008. Increasing nutrient concentrations and the rise and fall of a coastal fishery, a review of data from the Nile Delta, Egypt. Estuarine, Coastal and Shelf Science. 77: 309-319.

doi: 10.1016/j.ecss.2007.11.028

Özdemir N. 1994. Tatlı ve tuzlu sularda alabalık üretimi. Fırat Üniversitesi, Yayın No: 35, Elazığ. [in Turkish]

Öztürk B, Poutiers JM, Sarı HM, Özbek M. 2002. On the occurrence of Mytilaster marioni Locard, 1889 (Mollusca; Bivalvia; Mytilidae) in Lake Bafa (Turkey) with a redescription of the species. Hydrobiologia. 485:123-131. doi: 10.1023/A:1021374522187

Reghunath R, Murthy TRS, Raghavan BR. 2002. The utility of multivariate statistical techniques in hydrogeochemical studies: an example from Karnataka, India. Water Resour. 36: 2437-42. doi: 10.1016/s0043-1354(01)00490-0

Sarı HM, Balık S, Bilecenoğlu M, Türe G. 1999. Recent changes in the fish fauna of Lake Bafa, Aegean region of Turkey. Zool Middle East. 18: 67-76.

Sarı HM, Balık S, Özbek M, Aygen C. 2001. Bafa Gölü'nün makro ve meiobentik omurgasız faunası. Anadolu Üniversitesi Bilim ve Teknoloji Dergisi. 2(2):285-291. [in Turkish]

Shrestha S, Kazama F. 2007. Assessment of surface water quality using multivariate statistical techniques: a case study of the Fuji river basin, Japan. Environ Model Soft. 22:464-475.

doi: 10.1016/ j.envsoft.2006.02.001

Shuchun Y, Bin X, Deyang K. 2010. Chronology and nutrients change in recent sediment of Taihu Lake, lower changjiang river basin, East China. Chinese Geogr Sci. 20(3):202-208. doi: 10.1007/s11769-010-0202-1

Simeonova P, Simeonov V, Andreev G. 2003. Water quality study of the Struma River Basin, Bulgaria. Cent Eur J Chem. 1:136-212.

Solanki VR, Hussain MM, Raja SS. 2010. Water quality assessment of Lake Pandu Bodhan, Andhra Pradesh State, India. Environ Monit Assess. 163:411-419. doi: 10.1007/s10661-009-0844-6

Sommerfield PJ. 2008. Identification of the Bray-Curtis similarity index: Comment on Yoshioka (2008). Mar Ecol Prog Ser. 372:303-306. doi: 10.3354/meps07841

Svobodá Z, Lloyd R, Máchová J, Vykusová B. 1993. Water quality and fish health, FAO, EIFAC technical paper, No:54.
Tanyolaç J. 2004. Limnology (3rd edition). Hatipoğlu Press: Ankara. [in Turkish]

Taş B, Tepe Y, Ustaoğlu F, Alptekin S. 2019. Benthic algal diversity and water quality evaluation by biological approach of Turnasuyu Creek, NE Turkey. doi: 10.5004/dwt.2019.24225

TS266 2005. Sular-İnsani tüketim amaçlı sular. Türk Standartları Enstitüsü, ICS 13.060.20. [in Turkish]

Turkish Water Pollution Control Regulation (TWPCR). 2008. The regulation of water pollution control. ministry of environment and forestry. Official Newspaper, (31.12.2004) No: 25687.

Tokatlı C. 2020. Ergene Nehir Havzası su kalitesinin çok değişkenli istatistik analizler kullanılarak değerlendirilmesi. LIMNOFISH-Journal of Limnology and Freshwater Fisheries Research. 6(1):38-46. doi: 10.17216/limnofish.524036

Uncumusaoğlu AA, Mutlu E. 2019. Evaluating spatial and temporal variation in Tuzaklı pond water using multivariate statistical analysis. Pol J Environ Stud. 28(5):1-14. doi: 10.15244/pjoes/99103

Uslu O, Türkman A. 1987. Su kirliliği ve kontrolü. Ankara: T.C. Başbakanlık Çevre Genel Müdürlüğü Yayınları 398 s. [in Turkish]

Ustaoğlu F, Tepe Y. 2019. Water quality and sediment contamination assessment of Pazarsuyu Stream, Turkey using multivariate statistical methods and pollution indicators. International Soil and Water Conservation Research. 7(1):47-56.

doi: 10.1016/j.iswcr.2018.09.001

Ustaoğlu F, Tepe Y, Taş B. 2020. Assessment of stream quality and health risk in a subtropical Turkey river system: A combined approach using statistical analysis and water quality index. Ecol Indic. 113:105815. doi: 10.1016/j.ecolind.2019.105815

Wetzel RG. 2001. Limnology: Lake and river ecosystems. Elsevier Academic Press: 1006 p.

WHO (World Heath Organization). 2011. Guidelines for drinking-water quality. World Heath Organization Library Cataloguing-in-Publication Data, NLM classification: WA 675.

Yabanlı M, Türk N, Tenekecioğlu E, Uludağ R. 2011. Bafa Gölü'ndeki toplu balık ölümleri üzerine bir araştırma. SAÜ Fen Bilimleri Dergisi. 15(1):36-40. [in Turkish]

Yoshioka PM. 2008. Misidentification of the Bray-Curtis similarity index. Mar Ecol- Prog Ser. 368:309-310. doi: 10.3354/meps07728

Yu FC, Fang GH, Ru XW. 2010. Eutrophication, health risk assessment and spatial analysis of water quality in Gucheng Lake, China. Environ Earth Sci. 59: $1741-1748$. doi: 10.1007/s12665-009-0156-8

Zacheus OM, Martikainen PJ. 1997. Physicochemical quality of drinking and hot waters in Finnish buildings originated from groundwater or surface water plants. Sci Total Environ. 204:1-10. 
Zeybek M, Kalyoncu H, Ertan ÖO. 2012. Species composition and distribution of mollusca in relation to water quality. Turk J Fish Aquat Sci. 12:721-729.

doi: 10.4194/1303-2712-v12_3_21
Zhao Y, Xia XH, Yang ZF, Wang F. 2012. Assessment of water quality in Baiyangdian Lake using multivariate statistical techniques. Procedia Environ Sci. 13:1213-1226.

doi: 10.1016/j.proenv.2012.01.11 